\title{
ÜSTTEN AKIŞLI KAPAK AKIMININ SAYISAL MODELLEMESİ
}

\author{
Oğuz ŞiMSȘEK*
}

Harran Üniversitesi, Mühendislik Fakültesi, İnşaat Mühendisliği Bölümü, Şanlıurfa, Türkiye

\begin{abstract}
Anahtar Kelimeler Akışkan Hacimleri Yöntemi, Basınç Dağılımları, Daralma Katsayısl, Üstten Akışlı Kapak, Sayısal Modelleme.

\section{Öz}

Pivot savak olarak adlandırılan üstten akışlı kapaklar, açık kanal akımlarında akımı kontrol etmek ve düzenlemek için oldukça sık kullanılmaktadır. Pivot savaklar, istenilen seviyede su alma imkânı ve seviye kontrolü sağlamasından dolayı diğer savak türlerine göre daha avantajlıdır. Bu çalışmada, kanal tabanına farklı açılarda yerleștirilmiş üstten akışlı kapak üzerinden geçen akım sayısal olarak modellenmiştir. Sayısal modellemede akımı idare eden temel denklemler, sonlu hacimler yöntemine dayalı çözüm yapan ANSYS- Fluent paket programı yardımıyla, Reynolds Gerilme Modeli (Reynolds Stress Model-RSM) kullanılarak çözülmüştür. Su-hava arakesitinin belirlenmesinde ise akışkan hacimleri yöntemi kullanılmıştır. 6 farklı kapak açısında, RSM türbülans modeli kullanılarak elde edilen sayısal su yüzü profilleri, vena kontratta noktasının özellikleri ve daralma katsayıları, deneysel sonuçlarla karş̧laştııılmıştır. Karşılaştırma sonucunda, akım çizgilerinde eğriselliğin bulunduğu akımlarda başarılı sonuçlar veren RSM modelinin, farklı açılara sahip üstten akışlı kapak üzerinden geçen akımın sayısal modellemesinde başarılı olduğu belirlenmiștir. Ayrıca, sayısal olarak elde edilen hız, dinamik basınç ve akım çizgilerinin dağılımları değerlendirilmiștir.
\end{abstract}

\section{NUMERICAL MODELING OF OVERSHOT GATE FLOW}

\begin{tabular}{l}
\hline Keywords \\
Volume of Fluid Method, \\
Pressure Distribution, \\
Contraction Coefficient, \\
Overshot Gate, \\
Numerical Modeling.
\end{tabular}

\section{Keywords}

Contraction Coefficient,

Numerical Modeling.

\begin{abstract}
Overshot gates, called pivot weir, are often used to control the flow, and regulate flow depth in open channel flows. Pivot weirs are advantageous compared to other weir types because they provide the desired level of water intake and level control. In this study, the flow passing overshot gate placed at different angles to the channel bottom is numerically modeled. In numerical modeling, the basic equations that govern of the flow are solved using the Reynolds Stress Model (RSM) with the help of ANSYS-Fluent package program, which makes a solution based on finite volumes method. Volume of Fluid Method (VOF) was used to determine the water-air intersection. Numerical water surface profiles, the properties of the vena contract and contraction coefficients obtained using the RSM turbulence model at 6 different gate angles, were compared with experimental surface profiles and values. As a result of the comparison, it was determined that the RSM model, gives successful results in flows with curvature in the streamlines, is successful in numerical modeling of the overshot gate flow with different angles. In addition, velocity, dynamic pressure and streamlines distributions obtained numerically were evaluated.
\end{abstract}

\begin{tabular}{|c|c|c|}
\hline \multicolumn{3}{|c|}{$\begin{array}{l}\text { Alıntı / Cite } \\
\text { Şimşek, 0., (2020). Üstten Akışlı Kapak Akımının Sayısal Modellemesi, Mühendislik Bilimleri ve Tasarım Dergisi, } \\
8(3), 808-819 .\end{array}$} \\
\hline Yazar Kimliği / Author ID (ORCID Number) & Makale Süreci / Article Process & \\
\hline O. Şimșek, 0000-0001-6324-0229 & $\begin{array}{l}\text { Başvuru Tarihi / Submission Date } \\
\text { Revizyon Tarihi / Revision Date } \\
\text { Kabul Tarihi / Accepted Date } \\
\text { Yayım Tarihi / Published Date }\end{array}$ & \begin{tabular}{|l|}
15.06 .2020 \\
26.08 .2020 \\
04.09 .2020 \\
24.09 .2020
\end{tabular} \\
\hline
\end{tabular}

\footnotetext{
* ilgili yazar / Corresponding author: oguzsimsek@harran.edu.tr, +90-414-318-3000/3786
} 


\section{Giriş (Introduction)}

Savaklar akarsu, sulama ve drenaj kanallarında akım debisini ölçmek, savak memba bölgesinde su seviyesini belirlemek, kontrol etmek, düzenlemek ve dengelemek için sıklıkla kullanılan hidrolik yapılardır. Savaklar, akarsu veya kanal en kesitini tamamen kapatacak șekilde akıma dik doğrultuda inșa edilirler. Savak yapısının akım alanına inşa edilmesiyle, akarsu yatağında veya açık kanal içerisinde akım rejiminde değişiklikler meydana gelmektedir (savak membasında-kritik altı, savak üzerinde-kritik ve savak mansabında kritik üstü). Savak üzerinde oluşan kritik akım derinliğinin doğru belirlenmesiyle akımın debisi ölçülebilmektedir.

Savaklar, farklı tip ve geometride inşa edilmesinin yanında, genellikle keskin kenarlı veya geniş başlıklı tipleri diğer tiplere kıyasla daha yaygın olarak tercih edilmektedir. Üstten akışlı savaklar, akım alanına dik doğrultuda yerleştirilen, su ile temas eden yüzeyinin keskin olduğu düzlemsel plakalar olarak kullanılmaktadır. Pivot savak olarak da anılan üstünden akışlı kapaklar ile etkileşimde bulunan akımın, savak memba bölgesinde birikmesi ve sonrasında savak üzerinde aşması ne kadar karmaşık akım problemi olarak görülse de akımın savak üzerinden aşması durumunda düşey yöndeki akım hızı ve ivmesi önemli role sahip olmaktadır. Üstten akışlı savaklar, akımın memba bölgesinde meydana gelen dalgaları sönümleme, savak yüksekliğinin değişkenlik göstermesinden dolayı istenilen seviyede akım derinliğini ayarlama ve işletme kolaylığı sağlaması yönüyle, diğer savak tiplerine üstünlük sağlamaktadır. Üstten akışlı savaklar ve diğer savak türleriyle etkileşim halinde olan akımlarla ilgili fiziksel model çalışmaları laboratuvar ortamında gerçekleștirilebilmektedir (Harrison vd., 1969; Wahlin ve Replogle, 1994; Gonzalez ve Chanson, 2007; Machiels vd., 2011). Savak yapısının tasarımının gerçekleștirilebilmesi için akımın hız alanı, derinliği ve basınç dağılımı gibi bazı özelliklerin elde edilmesi gerekmektedir. Akımla ilgili bu özelliklerin elde edilmesi için özel ölçüm aletlerinin kullanılması zorunlu hale gelmektedir. Bu durum, fiziksel model çalışmaları yapan kişileri maddi olarak zorlamaktadır. Ayrıca, fiziksel model çalışmalarında, ölçüm yapılan aletlerin ve ölçümü yapan kişilerin ölçüm hassasiyetinden kaynaklı hatalarda bulunmaktadır. Son yıllarda teknolojide meydana gelen gelişmeler, bilgisayarların hidrolik mühendisliği alanındaki karmaşık problemlerin çözümünde kullanımını yaygınlaştırmıştır. Hesaplamalı Akışkanlar Dinamiği-HAD (Computational Fluid Dynamics-CFD) yöntemlerine dayalı bilgisayar yazılımlarında meydana gelen bu gelişmeler, farklı yapı ve akım kombinasyonları için akımla ilgili birçok parametrenin elde edilebilme kolaylığı sağlamaktadır. Ayrıca, bu yöntemler fiziksel model çalışmalarına kıyasla, akımla ilgili daha fazla bilgi edinme imkânı vermesinin yanında, fiziksel model çalışmasının gerçekleşmesi için kullanılan malzeme ve insan gücü açısından daha az kaynak gerektirmesiyle de büyük avantajlara sahiptir. Bilgisayar yazılımları, farklı su yapı etkileșiminin bulunduğu karmaşık akım problemlerin sayısal modellemesinde son yıllarda araştırmacılar tarafından oldukça sık kullanılmaktadır (Kirkgoz vd., 2008; Kirkgoz vd., 2009; Muslu, 2001; Aydın ,2012; Soydan vd., 2012; Akoz vd., 2014; Illkentapan ve Öner, 2017; Mahdavi ve Shahkarami, 2020; Soydan vd., 2020). Sayısal modellemenin yapıldığı çalışmalarda, Reynolds Gerilme Modeli (Reynolds Stress Model-RSM) akımda eğriselliğin, ayrılmaların ve ikincil akımların bulunduğu akım problemlerin çözümünde oldukça başarılı olan sonuçlar verdiği araştırmacılar tarafından belirtilmiştir. Ayrıca birçok çalışmada, su yüzü profillerinin belirlenmesi için akışkan hacimleri yönteminin tercih edildiği ve akışkan hacimleri yöntemi kullanılarak elde edilen su yüzü profillerinin deneysel bulgularla karşılaştırma sonucunda oldukça başarılı olduğu ifade edilmiştir.

Bu çalışmada, laboratuvar ortamında kanal tabanına farklı açılarda yerleştirilmiş üstten akışlı kapak üzerinden geçen akımın sayısal modellemesi yapılmıștır. Akımın hareketini idare eden temel denklemler, sonlu hacimler yöntemine dayalı olarak çözüm yapan ANSYS-Fluent paket programı yardımıyla, RSM türbülans modeli kullanılarak çözülmüștür. Su yüzünün teorik olarak belirlenmesinde ise Akışkan Hacimleri (Volume of Fluid-VOF) yöntemi kullanılmışır. Sayısal modellerden elde edilen akım su napı profilleri ve daralma katsayıları deneysel olarak elde edilen değerlerle karşılaştırılmıştır. Sayısal modellemenin üstten akışlı kapak akımını tahmin etmedeki başarısı değerlendirilmiştir. Bu çalışmada, deneysel ve sayısal model bulgularının karşılaştırılması sonucunda, sayısal model sonuçlarının güvenirliğinin artması ve sayısal model sonuçlarının doğrulanması amaçlanmıştır. Diğer bir ifadeyle farklı akım yapı etkileşimi problemlerinin çözümünde sayısal modelleme tekniklerinin kullanımına örnek olması hedeflenmiştir.

\section{Deneysel Çalışma (Experimental Study)}

Deneyler, Amerika Islah Kurumu (the US Bureau of Reclamation- USBR) tarafindan 1948 yllında laboratuvar ortamında yapılmıştır (USBR, 1948). USBR'da bulunan araştırmacılar tarafından üstten akışlı savaklara benzemesinden dolayı keskin kenarlı savak üzerinden geçen akım fiziksel olarak modellenmiştir. Çalışmada kullanılan keskin kenarlı savağın kret genişliği $1.2 \mathrm{~m}$, savak yüksekliği (p) kapak açısının $90^{\circ}$ olduğu durumda $0.61 \mathrm{~m}$ olarak ayarlanmıştır. Farklı açılarda gerçekleştirilen fiziksel model çalışmalarında $\mathrm{h}_{1} / \mathrm{p}$ değeri 0.5 olarak sabit alınmıştır (Şekil 1). Burada $\mathrm{h}_{1}$ savak kretinden su derinliğini temsil etmektedir. Farklı açı durumlarında bu oranın ayarlanması için açının azaldığı durumlarda savak yüzü uzunluğu arttırılmıștır. Fiziksel model çalışmalarında, kullanılan üstten akışlı kapak $\theta=90^{\circ}, 71.57^{\circ}, 56.31^{\circ}, 45^{\circ}, 26.57^{\circ}$ ve $14.04^{\circ}$ farklı açılarda tabana 
yerleştirilmiştir. 6 farklı kapak açıklığında su alt ve üst napının profili 387 l/s'lik debi durumu için elde edilmiştir. Akım üstten akışlı kapak üzerinden geçerek serbest dökülmesinden dolayı akım alanında eğrisel yörüngeye sahip olmaktadır. Bu eğriselliğin miktarının belirlenmesi için vena kontratta bölgesinin, savak kretine göre konumu deneysel olarak belirlenmiştir. Farklı kapak açılarında elde edilen vena kontratta bölgesinin özellikleri kullanılarak daralma katsayısı $\left(\mathrm{C}_{\mathrm{c}}\right)$ hesaplanmıștır.

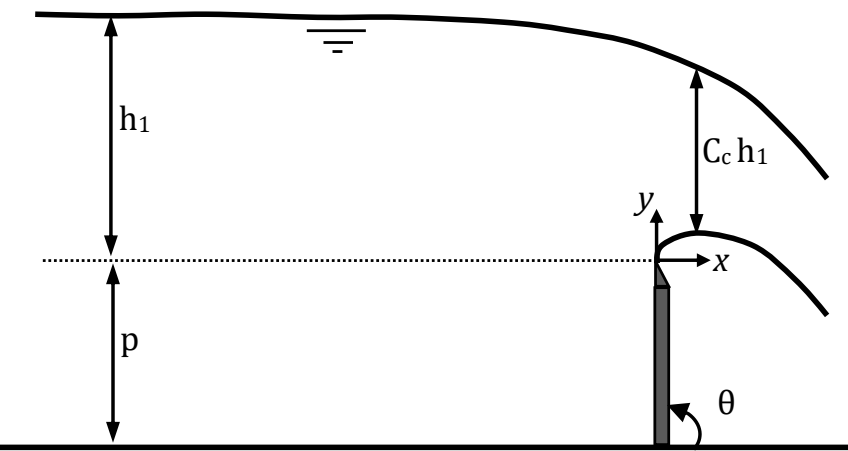

Şekil 1. Üstten akıșlı kapak akımının şematik gösterimi (Schematic view of overshot gate flow)

\section{Sayısal Modelleme (Numerical Modeling}

Fiziksel model çalışmalarının zaman ve insan gücü açısından oldukça masraflı olması, ölçek ve insan kaynaklı hataların sonuçlar üzerinde etkili olmasından dolayı, araştırmalar son yıllarda HAD tekniklerinin kullanıldığı bilgisayarlar yazılımlarının gelișmesiyle birlikte, sayısal model çalışmalarına yönelmiştir. Karmaşık akım problemlerinin fiziksel olarak çözülmesi ve akım ile ilgili bazı karakteristik büyüklüklerin elde edilme imkânı bulunmadığı durumlarda sayısal model çalışmaları oldukça etkin kullanılmaktadır. Dolusavak yapısının geometrisini oluşturan üstten akışlı kapak üzerinden geçen akımın analizinin doğru bir şekilde yapılması, yapı güvenliği ve verimliliği açısından önem arz etmektedir. Bu nedenle, üstten akışlı kapakla etkileşim halinde olan açık akımının fiziksel olarak modellemesi sonucunda elde edilen veriler sayısal model bulgularıyla karşılaştırılarak, sayısal modelleme sonuçlarının doğrulanması amaçlanmıştır. Akım alanında z doğrultusunda herhangi bir yapısal düzenlemenin bulunmamasından (daralma veya genişleme olmaması) dolayı ve üç boyutlu analizin iki boyutlu analizlere klyasla daha fazla zaman, depolama ve bilgisayar özelliği gerektirmesinden dolayı sayısal modellemede analizler iki boyutlu olarak gerçekleştirilmiştir.

\subsection{Temel Denklemler ve Türbülans Modeli (Basic Equations and Turbulence Model)}

Üstten akışlı kapak ile etkileşimde olan açık kanal akımı serbest yüzeyli, düzenli, iki boyutlu, sıkışmayan ve türbülanslı bir akım türüdür. Bu akım türünün hareketini idare eden temel denklemler (süreklilik, x ve y doğrultusundaki momentum) sırasıyla Eșitlik 1, 2 ve 3'te verilmiștir.

Kütlenin korunumu:

$$
\frac{\partial \bar{u}}{\partial x}+\frac{\partial \bar{v}}{\partial y}=0
$$

x doğrultusunda momentumun korunumu:

$$
\rho\left(\frac{\partial \bar{u}}{\partial t}+\bar{u} \frac{\partial \bar{u}}{\partial x}+\bar{v} \frac{\partial \bar{u}}{\partial y}\right)=\rho X-\frac{\partial \bar{p}}{\partial x}+\mu\left(\frac{\partial^{2} \bar{u}}{\partial x^{2}}+\frac{\partial^{2} \bar{u}}{\partial y^{2}}\right)+\frac{\partial \tau_{x x}}{\partial x}+\frac{\partial \tau_{x y}}{\partial y}
$$

y doğrultusunda momentumun korunumu:

$$
\rho\left(\frac{\partial \bar{v}}{\partial t}+\bar{u} \frac{\partial \bar{v}}{\partial x}+\bar{v} \frac{\partial \bar{v}}{\partial y}\right)=\rho Y-\frac{\partial \bar{p}}{\partial y}+\mu\left(\frac{\partial^{2} \bar{v}}{\partial x^{2}}+\frac{\partial^{2} \bar{v}}{\partial y^{2}}\right)+\frac{\partial \tau_{x y}}{\partial x}+\frac{\partial \tau_{y y}}{\partial y}
$$

Bu eşitliklerde yer alan $\bar{u}$ ve $\bar{v}$, sırasıyla $x$ ve $y$ doğrultusundaki zamansal ortalama hız bileşenlerini, $X$ ve $Y$ birim kütleye gelen kütlesel kuvvet bileşenlerini, $\bar{p}$ zamansal ortalama basıncı, $\mu$ dinamik viskoziteyi, $\rho$ akışkan yoğunluğunu ve $\tau_{\mathrm{xx}}, \tau_{\mathrm{xy}}$ ve $\tau_{\mathrm{yy}}$ türbülans (Reynolds) gerilmelerini ifade etmektedir. 
Yukarıda verilen temel eşitlikler, iki boyutlu bir akımda, $\mathrm{x}$ ve y doğrultusundaki iki hız bileşeni, bir adet basınç ve üç adet türbülans gerilmesi olmak üzere toplam 6 adet bilinmeyen içermektedir. Elde bulunan 3 adet eşitlik kullanılarak 6 adet bilinmeyenin çözümünün mümkün olmamasından dolayı, sayısal modellemede eşitlik sisteminin kapatılarak çözümün mümkün olması için, türbülans gerilmelerinin türbülans modelleri kullanılarak tanımlanması gerekmektedir. Boussinesq'in türbülans viskozitesi yaklașımına göre, türbülans kayma gerilmeleri doğrusal bünye denklemleriyle, sıkışmayan akımlar için Eşitlik 4, 5 ve 6'da verildiği gibi hesaplanmaktadır.

$$
\begin{aligned}
& \tau_{x x}=-\rho \overline{u^{\prime} u^{\prime}}=\mu_{t}\left(\frac{\partial \bar{u}}{\partial x}+\frac{\partial \bar{u}}{\partial x}\right)-\frac{2}{3} \rho k \\
& \tau_{x y}=-\rho \overline{u^{\prime} v^{\prime}}=\mu_{t}\left(\frac{\partial \bar{v}}{\partial x}+\frac{\partial \bar{u}}{\partial y}\right) \\
& \tau_{y y}=-\rho \overline{v^{\prime} v^{\prime}}=\mu_{t}\left(\frac{\partial \bar{v}}{\partial y}+\frac{\partial \bar{v}}{\partial y}\right)-\frac{2}{3} \rho k
\end{aligned}
$$

Burada, $u^{\prime}$ ve $v^{\prime}$ sırasıyla yatay ve düşey doğrultulardaki türbülans hız sapınçlarını, $\mu_{t}$ türbülans viskozitesini ve $k\left(=\overline{u_{i}^{\prime} u_{i}^{\prime}} / 2\right)$ türbülans kinetik enerjisini ifade etmektedir.

Yukarıdaki 4, 5 ve 6 eşitliklerinde bulunan $\mu_{t}$ 'nin hesaplanmasında, RSM türbülans modeli kullanılmıştır. RSM türbülans modelinde, Reynolds gerilme tansörünün tüm bileşenleri ve türbülans enerji kayıp oranı için ayrı ayrı taşınım denklemleri çözülmekte ve bu elde edilen bileşenler momentum eşitliklerinde doğrudan kullanılarak çözüm mümkün hala gelmektedir. RSM türbülans modeli akım çizgilerinde eğriselliğin bulunduğu, ikincil akımların mevcut olduğu ve akışkan parçacıklarının şekil değiştirme hızındaki aniden değişim gösterdiği akımlarda diğer türbülans modellerine kıyasla daha üstündür (Launder ve Spalding, 1972). Ayrıca, Reynolds gerilme tansörünü doğrudan çözmesi nedeniyle ikinci mertebe türbülans modeli olarak anılmaktadır. RSM türbülans modelinde kullanılan türbülans gerilmeleri için taşınım denklemleri $\left(R_{i j}=-\tau_{i j} / \rho=\overline{u_{i}^{\prime} u_{j}^{\prime}}\right)$ yazılarak momentum eşitliklerinden aşağıdaki gibi elde edilir (Launder ve Spalding, 1972).

$$
\begin{aligned}
\frac{d R_{i j}}{d t}=\frac{\partial R_{i j}}{\partial t}+ & \underbrace{\bar{u}_{k} \frac{\partial R_{i j}}{\partial x_{k}}}_{C_{i j}}=\underbrace{-\frac{\partial}{\partial x_{k}}\left[\overline{u_{i}^{\prime} u_{j}^{\prime} u_{k}^{\prime}}+\frac{1}{\rho}\left(\overline{p^{\prime} u_{i}^{\prime}} \delta_{j k}+\overline{p^{\prime} u_{j}^{\prime}} \delta_{k i}\right)\right]}_{D_{i j}^{\prime}}+\underbrace{v \frac{\partial^{2} \overline{u_{i}^{\prime} u_{j}^{\prime}}}{\partial x_{k} \partial x_{k}}}_{D_{i j}^{v}} \\
& -\underbrace{\overline{u_{i}^{\prime} u_{k}^{\prime}} \frac{\partial \bar{u}_{j}}{\partial x_{k}}-\overline{u_{j}^{\prime} u_{k}^{\prime}} \frac{\partial \bar{u}_{i}}{\partial x_{k}}}_{P_{i j}}+\underbrace{\overline{p^{\prime}\left(\frac{\partial u_{i}^{\prime}}{\partial x_{j}}+\frac{\partial u_{j}^{\prime}}{\partial x_{i}}\right)}}_{\Pi_{i j}}-\underbrace{2 v \frac{\partial u_{i}^{\prime}}{\partial x_{k}} \frac{\partial u_{j}^{\prime}}{\partial x_{k}}}_{\varepsilon_{i j}}
\end{aligned}
$$

Eşitlik (7)'de bulanan terimler, $R_{i j}$ 'nin: $C_{i j}$ konveksiyon ile taşınımını, $D_{i j}^{t}$ türbülans difüzyonu ile taşınımını, $D_{i j}^{v}$ viskoz difüzyon ile taşınımını, $P_{i j}$ zamansal üretim oranını, $\Pi_{i j}$ türbülans basınç-şekil değiştirme hızı etkileşimi ile taşınımını ve $\varepsilon_{i j}$ ise zamansal kayıp oranını temsil etmektedir.

Ayrıca, RSM türbülans modelinin dolusavaklar ve bu çalışmaya konu olan eğri yörüngeli akımlarda, kısmı gömülü silindir üzerinden geçen ve daha karmaşık akım türlerinin bulunduğu akım problemlerinin sayısal modellemesinde başarılı olduğu birçok çalışma tarafından belirtilmiştir (Amano ve Goel, 1984; Yakinthos vd., 2008; Akoz vd., 2014). Literatürde bulunan bu çalışmalar doğrultusunda bu çalışmanın sayısal modellemesinde RSM türbülans modeli kullanılmıştır.

\subsection{Akışkan Hacimleri Yöntemi (Volume of Fluid Method- VOF)}

Akışkan hacimleri yöntemi serbest yüzeyli akımlarda, su hava ara kesitinin belirlenmesinde oldukça sık kullanılmaktadır (Simsek vd., 2016; Soydan vd., 2017; Gümüş vd., 2018). Farklı araştırmacılar tarafından yapılan çalışmada su hava arakesitinin belirlenmesinde oldukça başarılı olduğu belirlenmiştir. Bu yöntemde, sayısal modellemede kullanılan hesaplama ağında, su ile havanın ara kesitindeki ağ elemanlarının hacimsel doluluk oranını esas almaktadır. Sayısal hesaplama ağına belirli bir zaman aralığında giren sıvının bu ağ elemanının hacmini doldurma oranını belirlemekte ve belirlenen zaman adımlarında akım profilinin hesaplanmasını gerçekleştirmektedir. Hacimsel doluluk oranını temsilen bir F fonksiyonu tanımlanmakta ve F=1 için ağ elemanı 
tamamen su ile tam dolu, F=0 için tamamen boş yani su bulunmamakta (hava ile dolu) ve $0<\mathrm{F}<1$ için kısmen suyla ve havayla dolu olmaktadır (Hirt ve Nichols, 1981). Bu yöntemle su hava arakesitinin belirlenmesi için "GeoReconstruct” yaklaşımı kullanılmıştır (ANSYS, 2012).

\section{3. Çözüm Bölgesi, Başlangıç ve Sınır Şartları (Solution Domain, Initial and Boundary Conditions)}

Sayısal modellemede kullanılan çözüm bölgesi ve sınırların isimleri Şekil 2'de verilmiştir. Sayısal çözüm bölgesinin alt sınırı $\mathrm{x}_{c ̧}-\mathrm{y}_{c ̧}$ koordinat takımının orijini olarak tanımlanmıştır. Üstten akışlı kapak, giriş sınırından $1 \mathrm{~m}$ ileriye yerleştirilmiş ve deneysel çalışmada belirtildiği gibi tüm açı durumları için aynı olmak üzere savak yüksekliği p $=0.61 \mathrm{~m}$, savak yükü $\mathrm{h}_{1}=0.30 \mathrm{~m}$ olarak alınmıştır. Deneysel çalışmada x ekseninde savaktan sonra $0.3 \mathrm{~m}$ 'lik uzunlukta alt ve üst nap profilleri sunulduğu için sayısal modellemede hesaplama süresini kısaltma tutmak üzere savak mansap bölgesinin uzunluğu $0.5 \mathrm{~m}$ olarak alınmıştır. Su hava arakesitinin daha iyi belirlenebilmesi için kesitte su bulunan bölgenin biraz üzerinde ( $\mathrm{y}=0.09 \mathrm{~m})$ üst sınır tanımlanmıştır. Sonuçların değerlendirilmesinde ise üstten akıșlı kapak kret noktası yeni tanımlanan x-y koordinat takımının orijini olarak alınmıștır. Sayısal modellemelerde kullanılan sınır șartları Tablo 1'de sunulmuştur. Katı sınır olan memba alt ve savak sınırları kaymayan duvar, yan, mansap alt, çıkış, üst ve giriş üst sınırında akımın hava ile temas ettiğini ifade etmek üzere p=0 pa şartı kullanılmıştır. Giriş sınırında, deneysel verilerden elde edilen yatay hız bileşeni u=0.355 m/s, düşey hız bileşeni v =0 m/s olarak tanımlanmıştır. Ayrıca giriş sınırında başlangıç şartı olarak, akışkan hacimleri yöntemi için hacimsel doluluk oranı olan F=1 olarak tanımlanarak suyun giriş kesitinin bu sınır olduğu belirtilmiștir. Ayrıca, yine bu sınırda başlangıç şartı olarak hidrolik çap $0.19 \mathrm{~m}$ ve türbülans şiddeti ise \%5 olarak verilmiştir. Çözüm bölgesinin tamamı başlangıçta tamamen boş kabul edilmiş olup yani F=0 olarak tanımlanmıştır. Sayısal çözümler zaman bağlı olarak gerçekleştirilmiştir. Zamana bağlı çözümde, iterasyon zaman adımı büyüklüğü Courant sayısı $\left(\mathrm{Cn}=\Delta \mathrm{t} /\left(\Delta \mathrm{x}_{\mathrm{ağ}} / \mathrm{v}_{\text {sıvı }}\right) ; \Delta \mathrm{t}\right.$ zaman adımı, $\Delta \mathrm{x}_{\mathrm{ağ}} \mathrm{x}$ doğrultusundaki ağ boyutu, $\mathrm{v}_{\text {sıvı }}$ akım hızı) $\mathrm{Cn} \leq 2$ olacak şekilde sayısal modellemede kullanılan paket program tarafından otomatik olarak ayarlanmıștır. Her bir iterasyon adımı arasında en fazla 10 iterasyon yapılmıştır.

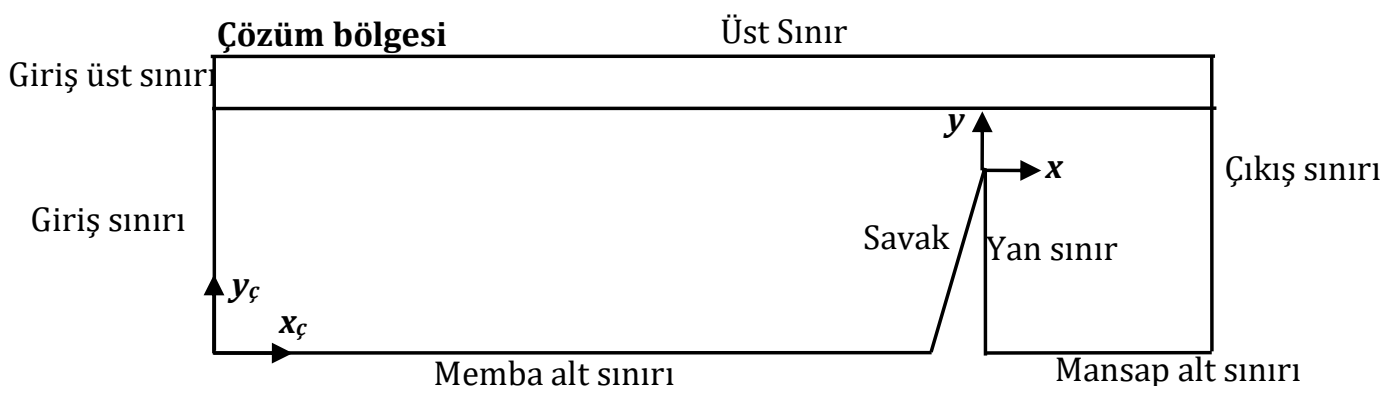

Şekil 2. Çözüm bölgesi ve sınırlar (Solution domain and boundaries)

Tablo 1. Sınır şartları (Boundary conditions)

\begin{tabular}{lll}
\hline Sınır & Tipi & Şart \\
\hline Giriș & Inflow & $\mathrm{u}=0.355 \mathrm{~m} / \mathrm{s}, \mathrm{v}=0 \mathrm{~m} / \mathrm{s}$ \\
\hline Giriş üst & Pressure outlet & $\mathrm{p}=0 \mathrm{pa}$ \\
\hline Memba alt & No slip & $\mathrm{u}_{\mathrm{i}}=0 \mathrm{~m} / \mathrm{s}$ \\
\hline Savak & No slip & $\mathrm{u}_{\mathrm{i}}=0 \mathrm{~m} / \mathrm{s}$ \\
\hline Yan & Pressure outlet & $\mathrm{p}=0 \mathrm{pa}$ \\
\hline Mansap alt & Pressure outlet & $\mathrm{p}=0 \mathrm{pa}$ \\
\hline Çıkış & Outlet & $\mathrm{p}=0 \mathrm{pa}$ \\
\hline Üst & Pressure outlet & $\mathrm{p}=0 \mathrm{pa}$ \\
\hline
\end{tabular}

\subsection{Sayısal Hesaplama Ă̆ı Tasarımı (Design of Numerical Computational Grid)}

Sayısal hesaplama ağı, sayısal model sonuçları üzerinde oldukça etkili olmaktadır. Sayısal modellemede kullanılacak hesaplama ağının çok küçük elemanlardan oluşması hesaplama süresinin artmasına yol açarken, aynı zamanda sayısal modellemenin gerçekleşmesi için yüksek donanımlı bilgisayar kullanımını gerekli kılmaktadır. Hesaplama ağının çok büyük elemanlardan oluşması ise hesaplama hatalarının büyümesine ve sayısal model sonuçlarının hassasiyetinin azalmasına neden olmaktadır. Bu nedenle en optimum hesaplama ağı tasarımının yapılması sayısal modelin başarısını doğrudan belirlemektedir. Bu çalışmada optimum hesaplama ağının tasarımında birçok çalışmada hesaplama ağı tasarımının uygunluğunu belirlemek amaciyla kullanılan ağ yakınsama indeksi (Grid Convergence Index-GCI) yöntemi kullanılmıștır (Roache, 1998; Oner vd., 2012; Gümüş vd., 2019; Gümüş vd., 2019; Soydan vd., 2020). Bu yöntem, en az üç farklı yoğunluğa sahip hesaplama ağı tasarımı 
zorunlu kılmaktadır. Gerekli analizler sonucunda elde edilen GCI $_{\text {ince }}$ değerinin \%2'den küçük olması durumunda, ağ yapısının sayısal model sonuçları üzerinde etkisinin olmadığı kabul edilmektedir. Ağ yakınsama indeksi analizi sonucunda elde edilen bulgulardan sayısal model sonuçlarının ağ yapısından bağımsızlaştığı görülmüştür. Bu çalışmaya konu olan tabana farklı açılarda yerleştirilmiş üstten akışlı kapak akımının sayısal modellemesinde kullanılan hesaplama ağı tasarımı Şekil 3'te verilmiştir. Çözüm bölgesi şekilde görüldüğü gibi 6 alt bölgeye ayrılmıştır. Hesaplama ağında 375,000 adet dikdörtgen eleman bulunmaktadır. Deneysel bulgular dikkate alındığında, sayısal modellemede kullanılan hesaplama ağının kapak kret ve mansap bölgesi daha küçük elemanlardan oluşturulmuştur. Böylelikle, deneysel bulgularla karşılaştıracak sonuçların daha hassas elde edilmesi sağlanmıştır. Ayrıca, savak memba bölgesinde mansap bölgesine kıyasla daha büyük elemanlar oluşturularak hesaplama süresinin kısalması amaçlanmıștır. Kapağın hemen üstünde ve kapak sonrası düşü bölgesinde ağ eleman boyutlarındaki değişimler $(\Delta x, \Delta y)$ Tablo 2'de verilmiştir. Tabloda verilen değerler mm cinsindendir. Tablodaki değerler incelendiğinde, her kapak açısı için y doğrultusundaki kapak uzunluğunun aynı olmasından dolayı ağ elemanının y doğrultusundaki $\triangle$ y aynı kalmıştır. Bunun yanında, kapak açısının azalmasıyla birlikte kapağın x doğrultusundaki uzunluğu artmış ve buna bağlı olarak ağ elemanın x doğrultusundaki boyutu kapak açısının azalmasıyla artmıştır. Ayrıca, tablodaki değerlerden, düşü öncesinde elde edilen $\Delta \mathrm{x}$ değerlerinin, düşü sonrası elde edilen değerlerden daha büyük olduğu anlaşılmaktadır. Kapak uzunluğunun en fazla olduğu $14.04^{\circ}$ durumunda elde edilen $y^{+}$değerlerinin değişimi Şekil $4^{\prime}$ te verilmiştir. Kapak ve kanal tabanının kesişim noktasından mansap bölgesine doğru ilerledikçe $\mathrm{y}^{+}$değerleri artmaktadır. Şekilden de görüleceği üzere maksimum $\mathrm{y}^{+}$değerinin kapak düşü noktasında yaklaşık olarak 12 olduğu görülmektedir. Bu değerin Kırkgöz ve Ardıçlıoğlu (1997) tarafından önerilen ilk ağ elemanının viskoz alt tabaka içerisinde kaldığının belirlenmesinde kullanılan referans değer olan 10 değerine oldukça yakın olduğu belirlenmiş ve çözüm alanı içerisinde sadece bu noktada bu değeri aşmasından dolayı hesaplamalarda bu ağ yapısı kullanılmıştır.

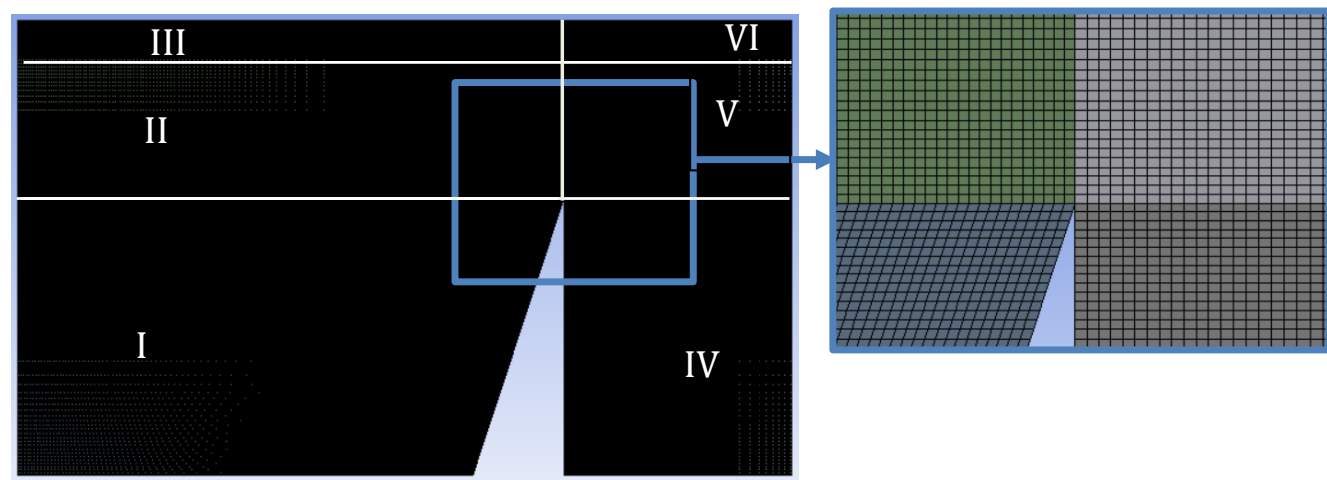

Şekil 3. $\theta=71.57^{\circ}$ için sayısal hesaplama ağı (Numerical computational grid for $\theta=71.57^{\circ}$ )

Tablo 2. Hesaplama ă̆ı boyutlarındaki değișim miktarları (mm) (Amounts of change in computational grid sizes)

\begin{tabular}{|c|c|c|c|c|c|c|c|c|c|c|c|c|}
\hline Açı & \multicolumn{2}{|c|}{$\theta=14.04^{\circ}$} & \multicolumn{2}{|c|}{$\theta=26.57^{\circ}$} & \multicolumn{2}{|c|}{$\theta=45^{\circ}$} & \multicolumn{2}{|c|}{$\theta=56.31^{\circ}$} & \multicolumn{2}{|c|}{$\theta=71.57^{\circ}$} & \multicolumn{2}{|c|}{$\theta=90^{\circ}$} \\
\hline Bölge /Değişim & $\Delta \mathbf{x}$ & $\triangle \mathbf{y}$ & $\Delta \mathbf{x}$ & $\triangle \mathbf{y}$ & $\triangle \mathbf{x}$ & $\triangle \mathbf{y}$ & $\Delta \mathbf{x}$ & $\triangle \mathbf{y}$ & $\triangle \mathbf{x}$ & $\triangle \mathbf{y}$ & $\Delta \mathbf{x}$ & $\triangle \mathbf{y}$ \\
\hline Düşü öncesi & 2.77 & 0.84 & 1.76 & 0.84 & 1.38 & 0.84 & 1.13 & 0.84 & 1.08 & 0.84 & 1.06 & 0.84 \\
\hline Düșü sonrası & 1.16 & 0.84 & 1.14 & 0.84 & 1.12 & 0.84 & 1.09 & 0.84 & 0.98 & 0.84 & 0.79 & 0.84 \\
\hline
\end{tabular}

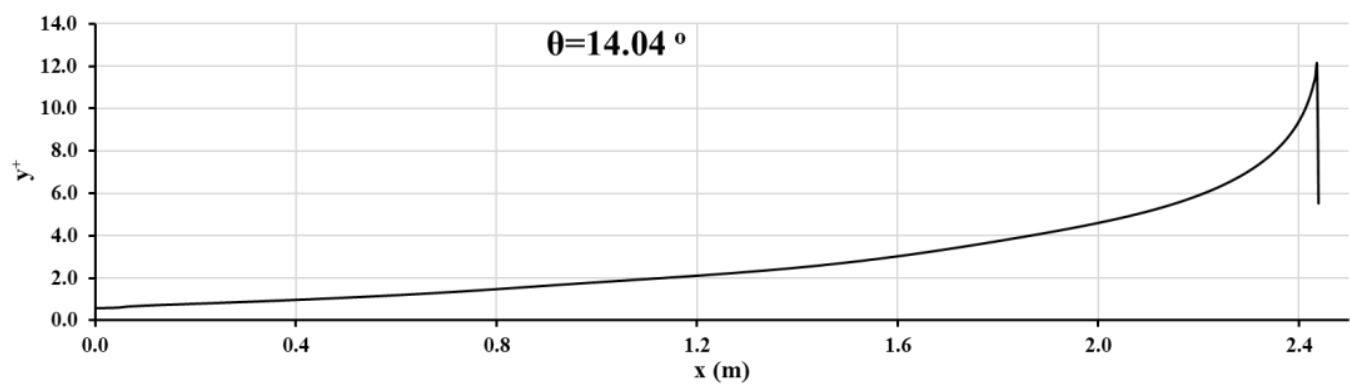

Şekil 4. Kapak üstünde oluşan $\mathrm{y}^{+}$değerinin değişimi $\left(\theta=14.04^{\circ}\right)$ (The change of the $\mathrm{y}^{+}$value on the gate)

\section{Bulgular ve Tartışma (Results and Discussion)}

Amerika Islah Kurumu (the US Bureau of Reclamation- USBR) tarafindan 1948 yılında laboratuvar ortamında elde edilen bulguların kapak sonrası düşü bölgesinde sunulmasından dolayı sayısal modellemelerde savak ve kanal tabanının kesişim noktası bulguların değerlendirilmesinde başlangıç noktası olarak değerlendirilmiştir. 
Böylelikle, sayısal model sonuçların daha anlaşılır olması da sağlanmıştır. Sayısal olarak elde edilen sonuçlar bu eksen takımı kullanılarak sunulmuştur.

\subsection{Deneysel ve Sayısal Su Yüzü Profilleri (Experimental and Numerical Water Surface Profiles)}

Şekil 5'te, tabana farklı açılarda yerleştirilmiş üstten akışlı kapak üzerinden geçen akımın deneysel ve sayısal olarak elde edilen alt ve üst nap profillerinin karşılaştırılması verilmiştir. Şekiller incelendiğinde, deneysel ve sayısal su yüzü profillerinin birbiriyle oldukça uyumlu olduğu görülmektedir. Üstten akışlı kapak açısının azalmasıyla, alt nap profilinin x eksenini kestiği mesafenin ve üst nap profilinin yüksekliğinin giderek azaldığı açıkça söylenebilir. Pivot savak eğiminin $\theta=45^{\circ}, 26.57^{\circ}$ ve $14.04^{\circ}$ olduğu durumda elde edilen deneysel ve sayısal alt ve üst nap profilleri arasındaki uyumun, $\theta=90^{\circ}, 71.57^{\circ}$ ve $56.31^{\circ}$ durumlarında elde edilen deneysel ve sayısal su yüzü profilleri arasındaki uyumda daha iyi olduğu belirlenmiştir. Bu sonuçtan, RSM modelinin akımda eğriselliğin artmasıyla su yüzü profilini belirlemedeki başarısının azaldığı ifade edilebilir.

RSM türbülans modeli kullanılarak sayısal olarak elde edilen su hava arakesitlerinin desenleri Şekil 6'da verilmiștir. Şekilde mavi renkli olarak gösterilen kısım suyu, kırmızı renkli gösterilen kısım ise havayı temsil etmektedir. Verilen şekiller incelendiğinde, akışkan hacimler yönteminin su hava arakesitinin belirlenmesinde oldukça başarılı olduğu görülmektedir. Sayısal modellemede kullanılan hesaplama ağının tasarımının su hava arakesitinin belirlenmesinde oldukça etkili olduğu ve küçük ağ elemanlarından oluşan hesaplama ağlarının su hava arakesitini daha büyük elemanlardan oluşan hesaplama ağlarına kıyasla daha hassas belirleme imkânı sunduğu belirlenmiștir.
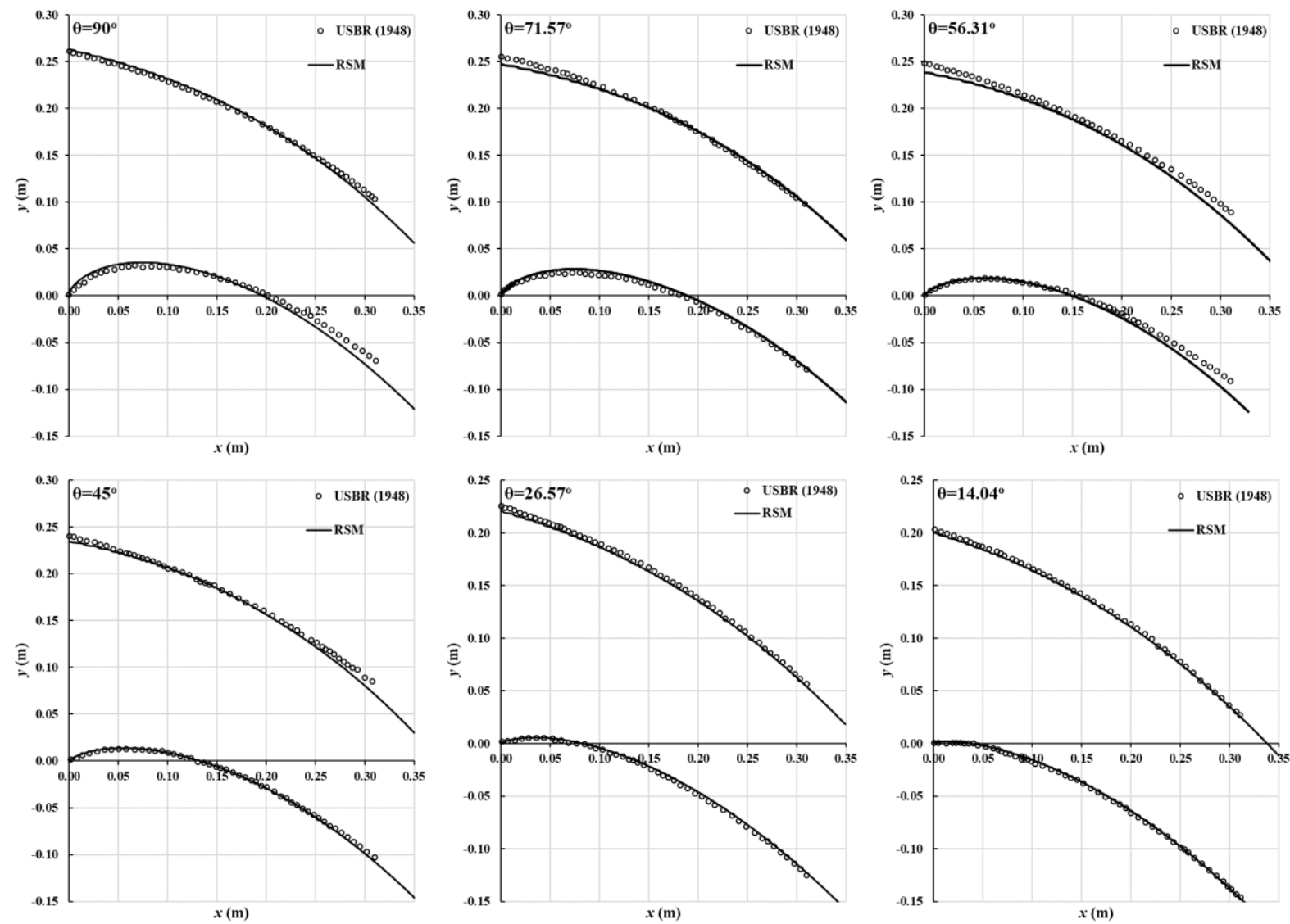

Şekil 5. Deneysel ve sayısal su yüzü profilleri (Experimental and numerical water surface profiles) 


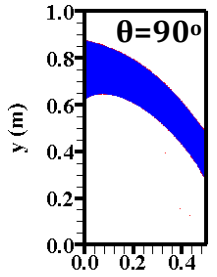

$\mathrm{x}(\mathrm{m})$
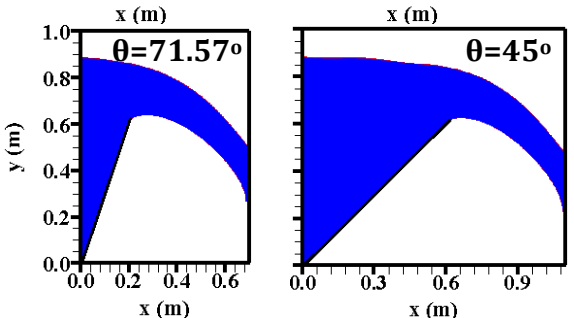
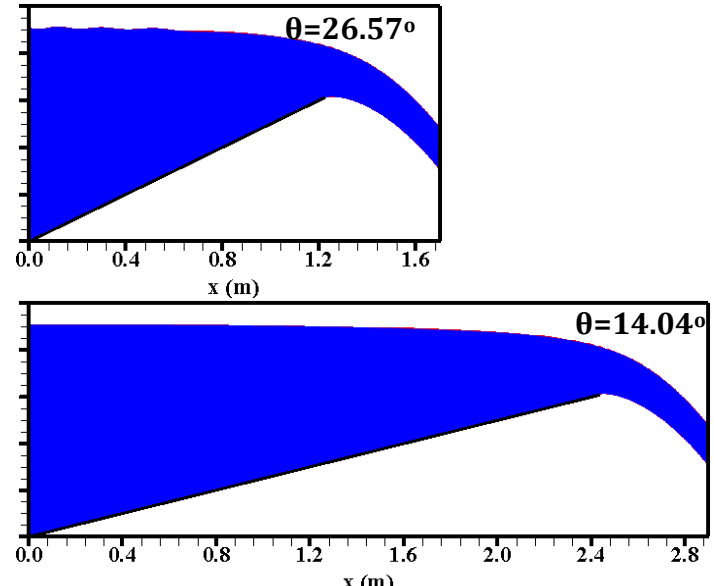

$\mathbf{x}(\mathbf{m})$

Şekil 6. Farklı kapak açılarında sayısal akım desenleri (Numerical flow patterns at different gate angles)

Kanal tabanına farklı açılarda yerleștirilmiș üstten akıșlı kapak akımının deneysel ve sayısal model sonuçlarından elde edilen vena kontratta bölgesine ait özellikler Tablo 3'te verilmiștir. Tablo verilen değerler incelendiğinde, deneysel ve sayısal olarak elde edilen vena kontratta noktasının $\mathrm{x}$ ve y ekseni değerlerinin hemen hemen aynı olduğu görülmektedir. Deneysel ve sayısal olarak elde edilen en büyük daralma katsayısı değerlerinin, savak açısının $45^{\circ}$ olduğu durumda elde edildiği, $45^{\circ}$ den daha büyük ve küçük savak açlarında daralma katsayısı değerinin azaldığı tablodaki değerlerden anlaşılmaktadır. Deneysel ve sayısal olarak elde edilen $\mathrm{x}$ ve y eksenleri değerlerinde milimetre düzeyinde çok küçük farklılıkların oluştuğu söylenebilir. Bu sonuçtan, RSM modelinin üstten akışlı kapak akımı üzerinde akımın en dar alana sahip olduğu vena kontratta noktasının yerini sayısal olarak belirlemede başarılı olduğu ifade edilebilir.

Tablo 3. Vena kontratta alanının özellikleri (Properties of the vena contracta area)

\begin{tabular}{cccc}
\hline \multicolumn{5}{c}{ Deneysel (USBR, 1948) } \\
\hline $\boldsymbol{\theta}(\mathbf{0})$ & x koordinatı (m) & Akım derinliği (m) & $\mathbf{C}_{\mathbf{c}}$ \\
\hline $\mathbf{9 0 . 0 0}$ & 0.075 & 0.204 & 0.669 \\
$\mathbf{7 1 . 5 7}$ & 0.070 & 0.209 & 0.688 \\
$\mathbf{5 6 . 3 1}$ & 0.061 & 0.210 & 0.690 \\
$\mathbf{4 5 . 0 0}$ & 0.058 & 0.219 & 0.718 \\
$\mathbf{2 6 . 5 7}$ & 0.030 & 0.211 & 0.692 \\
$\mathbf{1 4 . 0 4}$ & 0.015 & 0.197 & 0.647 \\
$\mathbf{0 . 0 0}$ & 0.000 & 0.155 & 0.508 \\
\hline \multicolumn{5}{c}{ Sayısal } \\
\hline $\boldsymbol{\theta ( 0 )}$ & x koordinatı (m) & Akım derinliği (m) & $\mathbf{C}_{\mathbf{c}}$ \\
\hline $\mathbf{9 0 . 0 0}$ & 0.074 & 0.206 & 0.665 \\
$\mathbf{7 1 . 5 7}$ & 0.074 & 0.203 & 0.655 \\
$\mathbf{5 6 . 3 1}$ & 0.061 & 0.204 & 0.659 \\
$\mathbf{4 5 . 0 0}$ & 0.055 & 0.207 & 0.669 \\
$\mathbf{2 6 . 5 7}$ & 0.034 & 0.205 & 0.661 \\
$\mathbf{1 4 . 0 4}$ & 0.015 & 0.193 & 0.624 \\
\hline
\end{tabular}

Deneysel ve sayısal olarak elde edilen daralma katsayısının $\left(\mathrm{C}_{\mathrm{c}}\right)$ farklı üstten akışlı kapak açılarına göre değişimleri Şekil 7'de verilmiştir. Şekil incelendiğinde, deneysel ve sayısal olarak elde edilen daralma katsayısının savak açısı ile değişiminin birbiriyle uyumlu olduğu açıkça söylenebilir. Bunun yanında, deneysel olarak elde edilen daralma katsayısının sayısal model sonucunda elde edilen daralma katsayısından daha büyük olduğu görülmektedir. Savak açısı $\theta=90^{\circ}, 71.57^{\circ}, 56.31^{\circ}, 45^{\circ}, 26.57^{\circ}$ ve $14.04^{\circ}$ olduğu durumlarda deneysel ve sayısal olarak elde edilen daralma katsayıları arasındaki fark sırasıyla \%1, \%5, \%5, \%7, \%4 ve \%4 olmuştur. Deneysel ve sayısal olarak elde edilen daralma katsayıları arasındaki maksimum farkın üstten akışlı kapak açısının $45^{\circ}$ olduğu durumda \% 7 , minimum farkın ise savak açısının $90^{\circ}$ olduğu durumda \%1 olduğu belirlenmiştir. Bu değerlerden görüldüğü üzere, deneysel ve sayısal olarak elde edilen daralma katsayıları arasındaki hata payının \%10 değerinden küçük olması sayısal model sonuçlarının deneysel bulgularla oldukça uyumlu ve kabul edilebilir hata sınırı içerisinde olduğu değerlendirilmiştir. 


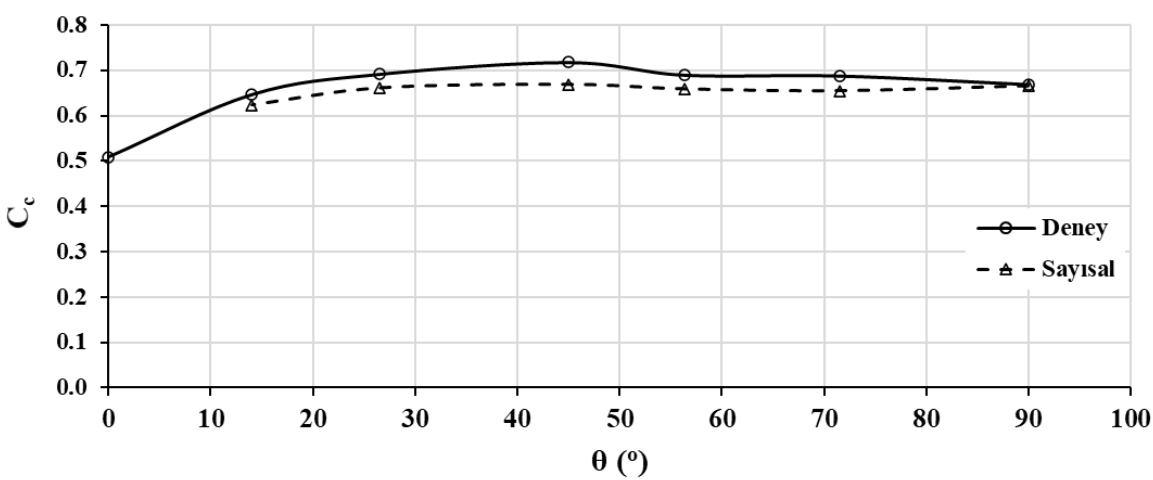

Şekil 7. Daralma katsayısının kapak açısına göre değișimi (The change of the contraction coefficient according to the angle of the gate)

\subsection{Akım Çizgileri Deseni (Streamlines Pattern)}

Farklı açılarda yerleştirilmiş üstten akışlı kapak akımının sayısal modellemesinden elde edilen akım çizgilerinin desenleri Şekil 8'de verilmiştir. Şekillerde üstten akışlı kapak yapısının alt sınırından itibaren akım çizgilerinin deseni değerlendirilmiş ve savak yapısının akım alanına olan etkisinin daha hassas belirlenmesi sağlanmıştır. Farklı açılarda sayısal modelleme sonucunda elde edilen akım çizgileri incelendiğinde, savak açısııın azalmasıyla savak memba bölgesinde akım çizgilerindeki eğriselliğin azaldığı görülmektedir. Ayrıca, savak açısının 90º, 71.57 o, $56.31^{\circ}$ ve $45^{\circ}$ olduğu durumda kanal tabanı ile üstten akışlı kapak alt sınırının birleștiği noktada akım çizgilerinin süreklilik göstermediği söylenebilir. Savak memba bölgesinde, akım çizgilerinin daha fazla eğrisellik gösterdiği açı durumlarında savak mansap bölgesinde bu eğriselliğin etkisiyle yatay mesafede daha az ilerleyebildiği belirlenmiştir. Diğer bir ifadeyle, memba bölgesinde eğriselliğin fazla olduğu savak açılarında akım mansap bölgesinde daha dik düşüler yapmak durumunda kalmıştır. Akım çizgilerinin deseninden, dolusavak mansap bölgesinin profilinin tasarlanma imkânı sunulmakta ve mansap bölgesinde yapıya zarar veren kavitasyon oluşumu gibi olumsuz akım koşullarının oluşmasının önlenmesi sağlanabilmektedir.
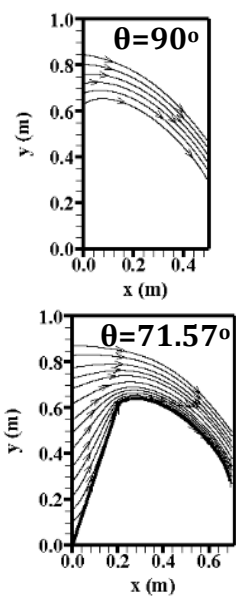
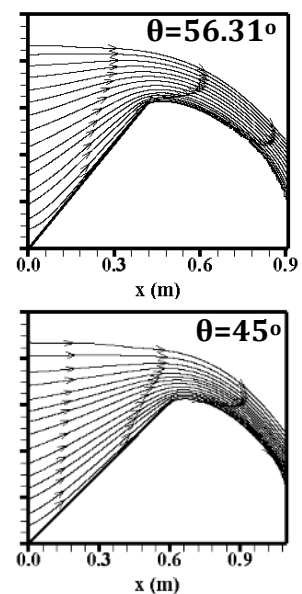
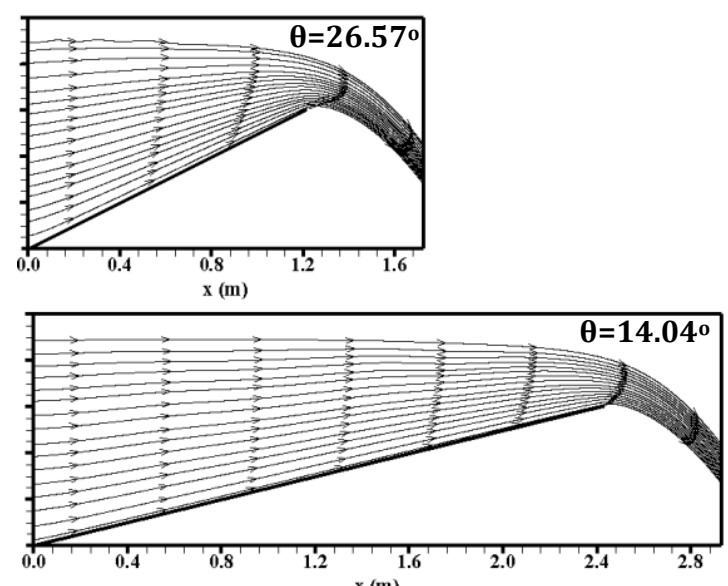

(m)

Şekil 8. Farklı açılarda sayısal olarak elde edilmiş akım çizgilerinin deseni (Pattern of streamlines numerically obtained at different angles)

\subsection{Hız Alanı (Velocity Field)}

Şekil 9'da, farklı üstten akışlı kapak açılarında sayısal olarak elde edilmiş bileşke hız kontörlerinin desenleri verilmiştir. Hız değerlerinin değişim aralığı aynı tutularak elde edilen hız desenlerinden değișen kapak açılarında akım alanın değerlendirilmesi sağlanmıştır. Verilen şekiller incelendiğinde, savak açısının azalmasıyla, $0.5 \mathrm{~m} / \mathrm{s}$ hızdan küçük hızların oluştuğu alanları artmaktadır. Ayrıca, akımın savak kretinden sonra hızlandığı ve en büyük hız değerlerine ( $3 \mathrm{~m} / \mathrm{s}$ 'den büyük) çözüm bölgesi sağ sınırında ulaşmaktadır. En büyük hız değerinin, düşü sonrası kanal tabanı üzerinde $3 \mathrm{~m} / \mathrm{s}$ değerinden daha büyük olacağı verilen şekillerden anlaşılmaktadır. Bunun yanında, farklı akım değerlerinin oluştuğu kontörlerin dağılımlarından bu düşü bölgesinde akımın eğri yörüngeye sahip olduğu anlaşılmaktadır. Bu eğrisellik savak açısının azalmasıyla birlikte artmaktadır. Akım hızının savak yapısının kret bölgesinde $1.5 \mathrm{~m} / \mathrm{s}$ ile $2 \mathrm{~m} / \mathrm{s}$ arasında değiştiği açıkça söylenebilir. Akımın yer çekiminin etkisiyle aşağı doğru hızlandığı ifade edilebilir. Savak sonrası düşü bölgesinde meydana gelen bu hız değerindeki artış, dolusavak topuk bölgesinde kativasyon oluşma ihtimali olan bölgenin tespitine olanak sağlamaktadır. 

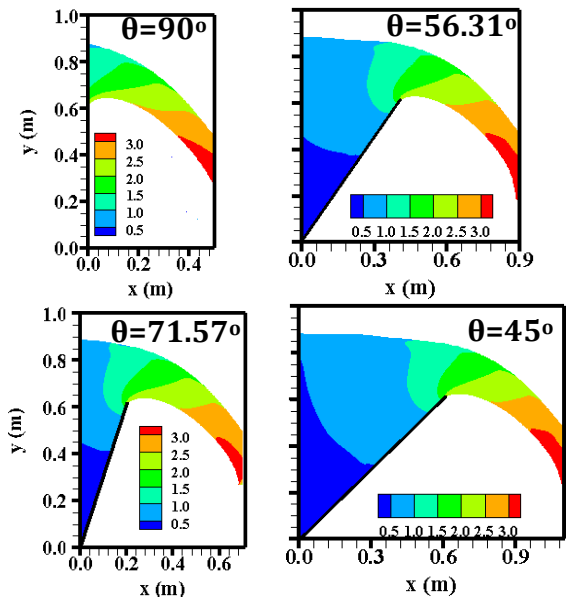

$\mathbf{x}(\mathbf{m})$
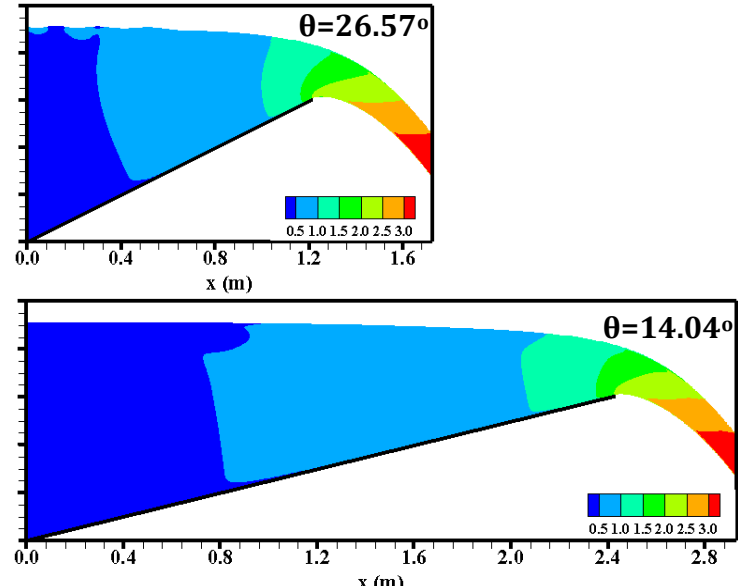

(m)

Şekil 9. Farklı savak açılarında sayısal olarak elde edilmiş hız dağılımları (Numerically obtained velocity distributions at different weir angles)

\subsection{Dinamik Basınç Dağılımı (Dynamic Pressure Distribution)}

Kanal tabanına farklı açılarda yerleştirilmiş üstten akışlı kapakla etkileşim halinde olan akımın sayısal modellemesinden elde edilen dinamik basınç dağılımları Şekil 10'da verilmiştir. Elde edilen şekiller incelendiğinde, üstten akışlı kapak yapısı üzerinde, basınç değerinin 500 Pa civarında oluştuğu ve bu değerin oluştuğu bölgenin büyüklüğünün savak açısının azalmasıyla arttığı görülmektedir. Kapak kreti mansap bölgesinde akım hızının artmasından dolayı, dinamik basınç değeri de düşü bölgesinin bitiş noktasında en büyük değerine sahip olmuştur. Çözüm bölgesinin ele alınan kısmında, maksimum basınç 5.000 Pa civarında oluşurken, minimum basınç ise $500 \mathrm{~Pa}$ civarında olmuştur. Elde edilen basınç dağıllımları genel olarak değerlendirildiğinde Şekil 9'da verilen hız dağılımına benzer olduğu görülmektedir. Hız profillerinde görülen akımda eğriselliğin oluşumu basınç dağılımlarından da benzer olarak anlaşılmaktadır. Ayrıca, düşü sonrası kanal tabanı üzerinde oluşacak dinamik basınç değerinin 5000 Pa değerinden daha büyük olacağı aşikardır. Kanal tabanında yapılacak düzenlemelerde bu basınç değerinin dikkate alınması taban malzemesi ve koruyucuların hesaplarını daha gerçekçi ve güvenli kılacaktır.
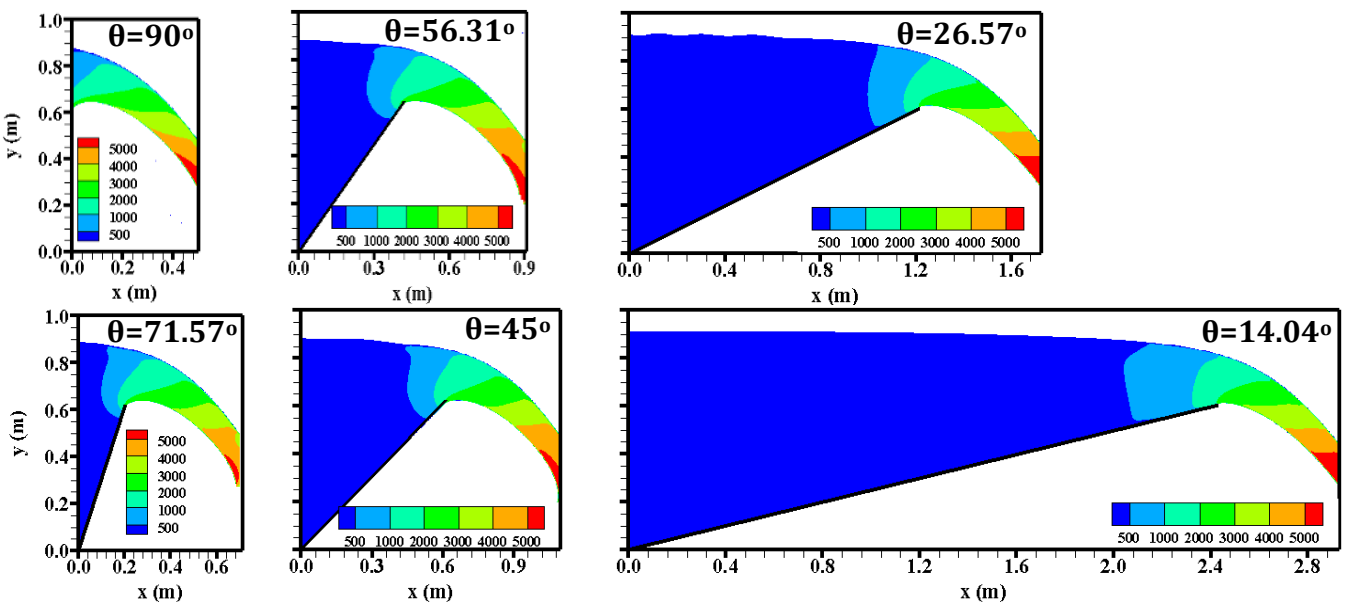

Şekil 10. Farklı savak açılarında sayısal olarak elde edilmiş dinamik basınç dağılımları (Dynamic pressure distributions numerically obtained at different weir angles)

Mahdavi ve Shahkarami (2020) tarafından farklı deneysel çalışmaya ait bulgular, hidrostatik düzeltmeli düzleştirilmiş parçacık dinamiği yöntemini (hydrostatic-corrected smoothed particle hydrodynamics) kullanılarak sayısal olarak modellenmiştir. Araştırmacılar deneysel olarak elde edilen bulguları sayısal model bulgularıyla karşılaştırarak sayısal model başarısı araştırmışlardır. Araştırmacılar tarafından debi katsayısının belirlenmesi için basit bir formül önerilmiştir. Bu çalışmada önerilen formül yardımıyla Mahdavi ve Shahkarami (2020) tarafından ele alınmayan $71.57^{\circ}$ ve $56.31^{\circ}$ savak açıları için debi katsayıları sırasıyla 0.681 ve 0.725 olarak elde edilmiștir. Bu çalışmada elde edilen akım hız değerlerinin, Mahdavi ve Shahkarami (2020) tarafından sunulan hız ve akım çizgileri desenlerinin benzer olduğu görülmektedir. Bu çalışmada sayısal modellemede su hava arakesitinin belirlenmesinde kullanılan akışkan hacimler yönteminin ve düşü bölgesinde daha küçük ağ elemanlarından oluşturulmasının sayısal model başarısını arttırdığı değerlendirilmiştir. Bunun yanında, yapılan bu çalışmada dinamik basınç dağılımlarının ve daralma katsayılarının değerlendirilmesinin literatüre katkı 
sunacağı düşünülmektedir. Mahdavi ve Shahkarami (2020) tarafından yapılan çalışmayla, ele alınan bu çalışmanın farklı yöntemler kullanılarak benzer sonuçlar elde edildiği görülmekte ve sayısal modelleme tekniklerinin bu tür akım problemlerin çözümünde kullanılabileceği söylenebilir.

\section{Sonuçlar (Conclusions)}

Pivot savaklar, savak yüksekliğinin değişkenlik gösterebilme özelliğinden dolayı, istenilen akım durumunda ve akım seviyesinde akımı kontrol etmeyi sağlama avantajına sahip olmasından dolayı diğer savak tiplerine kıyasla daha sık kullanılmaktadır. Savak eğiminin değişkenlik göstermesi, savağın su tutma kapasitesini arttırmasının yanında akım iletim özelliğini de büyük derecede olumlu yönde etkilemektedir. Deneysel olarak oldukça zahmetli olan model çalışmalarının son yıllarda gelişen teknolojiyle paralel yerinin sayısal model çalışmalarına bıraktığı görülmektedir. Bu çalışmada farklı açılara sahip pivot savak üzerinden geçen akımın sayısal modellemesi yapılmıștır. Sayısal modellemede pivot savak akımını idare eden temel denklemler sonlu hacimler yöntemi yardımıyla, Reynolds Ortalamalı Naviver Stokes (RANS) denklemlerine dayanan Reynolds Gerilme Modeli kullanılarak çözülmüştür. Sayısal modellemelerde, akım profilinin belirlenmesi için ise akışkan hacimleri yöntemi kullanılmıştır. Sayısal olarak elde edilen daralma katsayısı, vena kontratta nokta özellikleri, su alt ve üst nap profilleri deneysel bulgularla karşılaştırılmıştır. Karşılaştırma sonucunda, deneysel ve sayısal profillerin birbiriyle oldukça uyumlu olduğu görülmüştür. Sayısal olarak elde edilen daralma katsayıları değerleri deneysel değerlere oldukça yakındır. Sayısal modelleme sonucunda elde edilen akım çizgilerinin deseninden kapak açısının artmasıyla, kapağın kanal tabanıyla birleşim noktasında ayrılmaların bulunduğu belirlenmiştir. Dinamik basınç ve bileşke hız dağılımının benzer olduğu ve savak mansap bölgesinin en uç noktasında en büyük değere sahip olduğu görülmüştür. Dolusavak mansap profilinin savak ön eğiminin değișimine bağlı değişimi belirlenmiştir. Çalışma sonucunda, RSM türbülans modelinin üstten akışlı kapak üzerinden geçen eğrisellik gösteren akımın sayısal modellemesinde başarılı olduğu belirlenmiştir. Sayısal model bulguları kullanılarak akımların yapılarla etkileşimde bulunduğu hidrolik problemlerinin çözümü yapılabilmekte, yapıların tasarım aşamasında alınacak güvenlik tedbirleri hidrolik yapıların inşasından önce alınabilecektir. Ayrıca, sayısal modellemeler aracılığıyla tasarım ve performans analizi için gerekli parametrelerin fiziksel modellere kıyasla daha az masrafla analiz edilebileceği görülmüștür.

\section{Çıkar Çatışması (Conflict of Interest)}

Yazar tarafından herhangi bir çıkar çatışması beyan edilmemiştir. No conflict of interest was declared by the author.

\section{Kaynaklar (References)}

Akoz, M. S., Gumus, V., Kirkgoz, M. S., 2014. Numerical Simulation of Flow over a Semi-cylinder Weir. Journal of Irrigation and Drainage Engineering, $140(6), 04014016$.

Amano, R. S., Goel, P., 1984. A Numerical Study of a Separating and Reattaching Flow by Using Reynolds-Stress Turbulence Closure. Numerical Heat Transfer, 7(3), 343-357.

ANSYS, 2012. FLUENT Theory Guide. USA: ANSYS Inc.

Aydin, M. C., 2012. CFD Simulation of Free-Surface Flow over Triangular Labyrinth Side Weir. Advances in Engineering Software, 45(1), 159-166.

Gonzalez, C. A., Chanson, H., 2007. Experimental Measurements of Velocity and Pressure Distributions on a Large Broad-Crested Weir. Flow Measurement and Instrumentation, 18(3-4), 107-113.

Gümüş, V., Şimşek, O., Soydan, N. G., Aköz, M. S., Kırkgöz, M. S., 2018. Akışkan Hacimleri Yöntemiyle Yapılan Sayısal Modellemelerde Yan Duvar Etkisinin İncelenmesi. Harran Üniversitesi Mühendislik Dergisi, 3(3), 15-21.

Gümüș, V., Parmaksız, M., Şimșek, O., Avşaroğlu, Y., 2019. Farklı Akım Koşullarına Sahip Serbest Hidrolik Sıçramanın Deneysel ve Sayısal Modellemesi. Bilecik Șeyh Edebali Üniversitesi Fen Bilimleri Dergisi, 6(2), 447-466.

Gümüş, V., Şimşek, O., Bal, Ș,. 2019. Değişken Enkesitli Açık Kanal Akımının Deneysel ve Sayısal Modellemesi. Gazi Üniversitesi Fen Bilimleri Dergisi Part C: Tasarım ve Teknoloji, 7(4), 938-956.

Harrison, A. J. M., Montes, S., Manning, A., Halliwell, A., Williams, J., Markland, E., Allen, J., Hill, J. A., Bunt, E. A., Abbott, M. B., Smith, C. D., Herschy, R. W., Engel, F. V. A., Hall, G. W., 1969. The Streamlined Broad-Crested Weir. Proceedings of the Institution of Civil Engineers, 42(4), 575-599.

Hirt, C. W., Nichols, B. D., 1981. Volume of Fluid (VOF) Method for the Dynamics of Free Boundaries. Journal of Computational Physics, 39(1), 201-225.

İlkentapar, M., Öner, A., 2017. Geniș Başlıklı Savak Etrafındaki Akımın İncelenmesi. Niğde Ömer Halisdemir Üniversitesi Mühendislik Bilimleri Dergisi, 6 (2), 615-626.

Kirkgöz MS, Ardiçlioğlu M. 1997. Velocity Profiles of Developing and Developed Open Channel Flow, Journal of Hydraulic Engineering, 123(12),1099-105.

Kirkgoz, M. S., Akoz, M. S., Oner, A. A., 2008. Experimental and Theoretical Analyses of Two-Dimensional Flows Upstream of Broad-Crested Weirs. Canadian Journal of Civil Engineering, 35(9), 975-986.

Kirkgoz, M. S., Akoz, M. S., Oner, A. A., 2009. Numerical Modeling of Flow over a Chute Spillway. Journal of Hydraulic Research, 47(6), 790-797. 
Launder, B. E., Spalding, D. B., 1972. Lectures in Mathematical Models of Turbulence, New York. Academic Press.

Machiels, O., Erpicum, S., Dewals, B. J., Archambeau, P., Pirotton, M., 2011. Experimental Observation of Flow Characteristics over a Piano Key Weir. Journal of Hydraulic Research, 49(3), 359-366.

Mahdavi, A., Shahkarami, N., 2020. SPH Analysis of Free Surface Flow over Pivot Weirs. KSCE Journal of Civil Engineering, 1-12.

Muslu, Y., 2001. Numerical Analysis for Lateral Weir Flow. Journal of Irrigation and Drainage Engineering, 127(4), $246-253$.

Oner, A. A., Akoz M. S., Kirkgoz M. S., Gumus V., 2012. Experimental Validation of Volume of Fluid Method for a Sluice Gate Flow. Advances in Mechanical Engineering, 4, 461708.

Roache, P. J., 1998. Verification of Codes and Calculations, AIAA Journal, 36(5), 696-702.

Simsek, O., Akoz, M. S., Soydan, N. G., 2016. Numerical Validation of Open Channel Flow over a Curvilinear Broad-Crested Weir. Progress in Computational Fluid Dynamics, an International Journal, 16(6), 364-378.

Soydan Oksal, N. G., Akoz, M. S., Simsek, O., 2020. Numerical Modelling of Trapezoidal Weir Flow with RANS, LES and DES Models. Sadhana, 45(1), 91.

Soydan, N. G., Aköz, M. S., Șimșek, O., Gümüș, V., 2012. Trapez Kesitli Geniș Bașlıklı Savak Akımının k-e Tabanlı Türbülans Modelleri ile Sayısal Modellenmesi. Çukurova Üniversitesi Mühendislik-Mimarlık Fakültesi Dergisi, 27(2), 47-58.

Soydan, N. G., Simsek, O., Aköz, M. S., 2017. Prediction and Validation of Turbulent Flow around a Cylindrical Weir. European Water, 57, 85-92.

USBR (1948). Studies of Crests for Overfall Dams. Bulletin 3. Boulder Canyon Project, Final Report. US Bureau of Reclamation, US Dept. of Interior, Denver, CO. 186 pp.

Wahlin, B. T., Replogle, J. A., 1994. Flow Measurement Using an Overshot Gate. UMA Engineering, 1-25.

Yakinthos, K., Vlahostergios, Z., Goulas, A., 2008. Modeling the Flow in a 90 Rectangular Duct Using one Reynolds-Stress and Two Eddy-Viscosity Models. International Journal of Heat and Fluid Flow, 29(1), 35-47. 